\title{
Research on the Development Countermeasure of Supply Side Reform of China's Productive Service Industry Based on System Dynamics
}

\author{
Xiaoyu Wang ${ }^{1, a}$, Qian Wang ${ }^{2, b^{*}}$ and Yuxin Zhao ${ }^{3, c}$ \\ ${ }^{1,2,3}$ Dalian Neusoft Institute of Information, Dalian, China \\ aawangxiaoyu@neusoft.edu.cn, ${ }^{b}$ wangqian@neusof.edu.cn, ${ }^{c}$ zhaoyuxin@neusoft.edu.cn
}

\begin{abstract}
Keywords: System dynamics; Productive service industry; Supply side reform; Development countermeasure
\end{abstract}

\begin{abstract}
Based on the development problem of productive service industry in China, this paper focuses on the influencing factors and development countermeasures of supply side reform of productive service industry in China. This paper establishes the system dynamics model of the supply side reform of productive services industry in China by using the system dynamics method, Through the analysis of the causality feedback loop, the development countermeasures for the supply side reform of productive service industry in China are put forward, which provides a reference for the formulation of corresponding policies. So as to promote the development of supply side reform of productive services in China.
\end{abstract}

\section{Introduction}

In November 2015, after the supply side structural reforms were put forward, the provinces and cities in China were carrying out the supply side reform of the productive service industry in depth. It is not only the need of carrying out the decision-making and deployment of the State Council and speeding up the structural reform on the supply side, but also the need of the transformation and upgrading of the industrial structure and conforming to the development trend of the high growth of the service industry. At the same time, domestic and foreign scholars' research on the factors and development countermeasures of productive service industry based on the supply side structural reform perspective has been increasing. With the increasing proportion of China's service industry in GDP, the supply side structural reform of productive services is becoming more and more important. Therefore, it is of great practical significance for China to study the key factors and development countermeasures of the productive service industry from the perspective of supply side structural reform.

\section{Introduction to the productive service industry}

In the 1960s, American economist H. Greenfield first proposed the concept of a productive service industry. At present, the definition of productive services has not been unified by domestic and foreign scholars. Some scholars put forward the connotation of the productive service industry from the perspective of demand, while other scholars conduct research on service objects and service activities[1]. When foreign scholars Singelman and Browning studied the classification of service industry in the 1970s, they thought that producer services should cover finance, law, industry and commerce, insurance and other industries. In the 1980s, Hubbard and Daniels believed that the service industry should include both productive and consumptive services. They pointed out that the other service fields should be the producer services except consumptive services. Research scholar Hansen pointed out in the 1990s that productive services can play an intermediate role as inputs to goods production or other services. Productive services should cover activities such as upstream R\&D design and downstream markets. In 2000, research scholar Coffer pointed out that productive services should be an intermediate input, which can not directly produce utility and direct consumption. It is used to produce other products or services, and plays an important role in the intermediate link. However, according to the in-depth study of productive services industry by scholars in all aspects, it is not difficult to find that there are 
some common points. In short, the productive service industry provides services for the manufacturing industry and is compatible with the manufacturing industry. The productive services exist in all aspects of the manufacturing industry. It provides $R \& D$, finance, logistics, information, insurance and other related service products for manufacturing process[2].

\section{The Significance of the Development of Productive Service Industry under the Background of Supply Side Reform}

In order to improve the quality and efficiency of the supply system, and thus enhance the momentum of sustained growth of the national economy, the state in November 2015 called for the strengthening of the supply-side structural reform, while appropriately expanding overall demand. With the deepening of development plans such as "One Belt and One Road" and "Made in China 2025", the productive service industry, as the "midfield engine" for industrial transformation, has become the key to accelerating the integration and coordinated development of the three industries.

In recent years, China's service industry has developed rapidly, and the proportion of service industry in GDP has been significantly increased. Especially, with China becoming a manufacturing base in the world, the demand for productive services has expanded rapidly. In 2015, China's service industry accounted for $50.2 \%$ of GDP, breaking through $50 \%$ for the first time. However, compared with developed countries and even developing countries, this proportion is still low, showing a phenomenon that is inconsistent with the trend of world economic service development. In 2016 and 2017, the service industry accounted for $51.6 \%$ of GDP, of which the productive service industry played a key role. At present, China's manufacturing industry has formed a huge constraint on the development of the productive service industry, and China's productive service industry is still at a relatively low level. Traditional service industries such as transportation, wholesale, and retail account for a large proportion, while high-end productive service industries with high technology content and strong driving force such as $\mathrm{R} \& \mathrm{D}$, design, and brand marketing are obviously underdeveloped[2]. These problems in the development of China's productive service industry are actually accompanied by problems such as the transformation of China's economic growth mode, industrial upgrading and the improvement of international competitiveness. Therefore, accelerating the development of the productive service industry will undoubtedly help to solve these problems.

\section{System Dynamics Model of Supply Side Reform of China's Productive Service Industry}

The study of system dynamics originated from the masterpiece Industrial Dynamics by Professor Jay W. Forrester of the Massachusetts Institute of Technology in the late 1950s. Initially, it mainly applied industrial enterprise management to deal with such problems as changes in production and employee conditions, market inventory and market growth instability. Nowadays, the application of system dynamics is very wide, from civilian to military; from the management of scientific research and design work to urban decision-making, from the threat of exponential growth and the crisis of world resource depletion to the pathological hypothesis of diabetes, the application range is very wide[3].

Systematic Analysis of the Development of Productive Service Industry in the Supply Side. General Secretary Xi Jinping clearly pointed out that the ultimate goal of the supply side structural reform is to improve the quality and efficiency of the supply system and meet the growing demand. The fundamental approach is to deepen reform. The supply side includes three successive levels of production factors, producers and industries.

Therefore, the factors affecting the development of productive service industry under the background of supply side reform involve three subsystems: production factor, industrial environment and manufacturing. When discussing the supply side structural reform measures of producer services, these three main subsystems should be considered comprehensively. The relevant influencing factors, So as to formulate development countermeasures for the reform of productive service industry.

Labor, technology, capital, land and resources in the subsystem of factors of production are the core elements of production needs. In order to promote structural reforms in supply, efforts must be made to 
improve the quality and distribution efficiency of production factors, including the improvement of labor quality, technology supply, and financial services, and promote reforms such as land systems and resource and environmental systems. The quantity and quality of production factors are very important for the development of China's productive service industry. On the one hand, the number of production factors is increasing, and the development opportunities of China's productive service industry are increasing; on the other hand, high quality production factors are important inputs for the development of productive service industry in China.

Promoting industrial transformation and upgrading is the central task of promoting supply reform, and the industrial structure must meet the development requirements of the productive service industry. Only when the industrial supply meets the market demand and the industrial structure adapts to the demand structure can the scarce factor resources be effectively allocated and utilized, and the economy can achieve sustainable development. At the same time, it is necessary to increase support for industrial finance, related laws and policies to create a quality industrial environment.

The manufacturing industry promotes mutual development with the productive service industry, and it is the basis for the development of the productive service industry. With the increase in the production value of the manufacturing industry, the demand for the productive service industry will continue to increase, which will eventually lead to an increase in the supply capacity of the productive service industry.

Based on the above analysis, the main influencing factors of the development of the productive service industry under the background of supply side reform are shown in Table 1.

Table 1 Main Influencing Factors of the Development of Productive Service Industry under the Background of Supply Side Reform

\begin{tabular}{c|l|l}
\hline Factors of production & Industrial environment & manufacturing \\
\hline labor & industrial structure & government investment \\
\hline capital & financial support & manufacturing output \\
\hline technology & related laws and policies & manufacturing demand \\
\hline land & & \\
\hline
\end{tabular}

System Dynamics Model and Analysis of Supply Side Reform of China's Productive Service Industry. Professor J.W. Forrester of the Massachusetts Institute of Technology first proposed the idea of system dynamics in the 1960s. The system dynamics model is a computer simulation method for studying the dynamic behavior of feedback systems for complex real-world problems. Through the computer simulation of the system dynamics model, it provides an important theoretical basis for the development decision-making[5].

China's productive service industry supply side reform causality model. According to the system dynamics modeling method, the three subsystems of production factors, industrial environment and manufacturing that affect the development of the productive service industry in the supply side are analyzed, and the causality model is drawn according to the influencing factors affecting the three subsystems. [6]. The causal relationship model of the supply side reform system of China's productive service industry is shown in Figure 1 


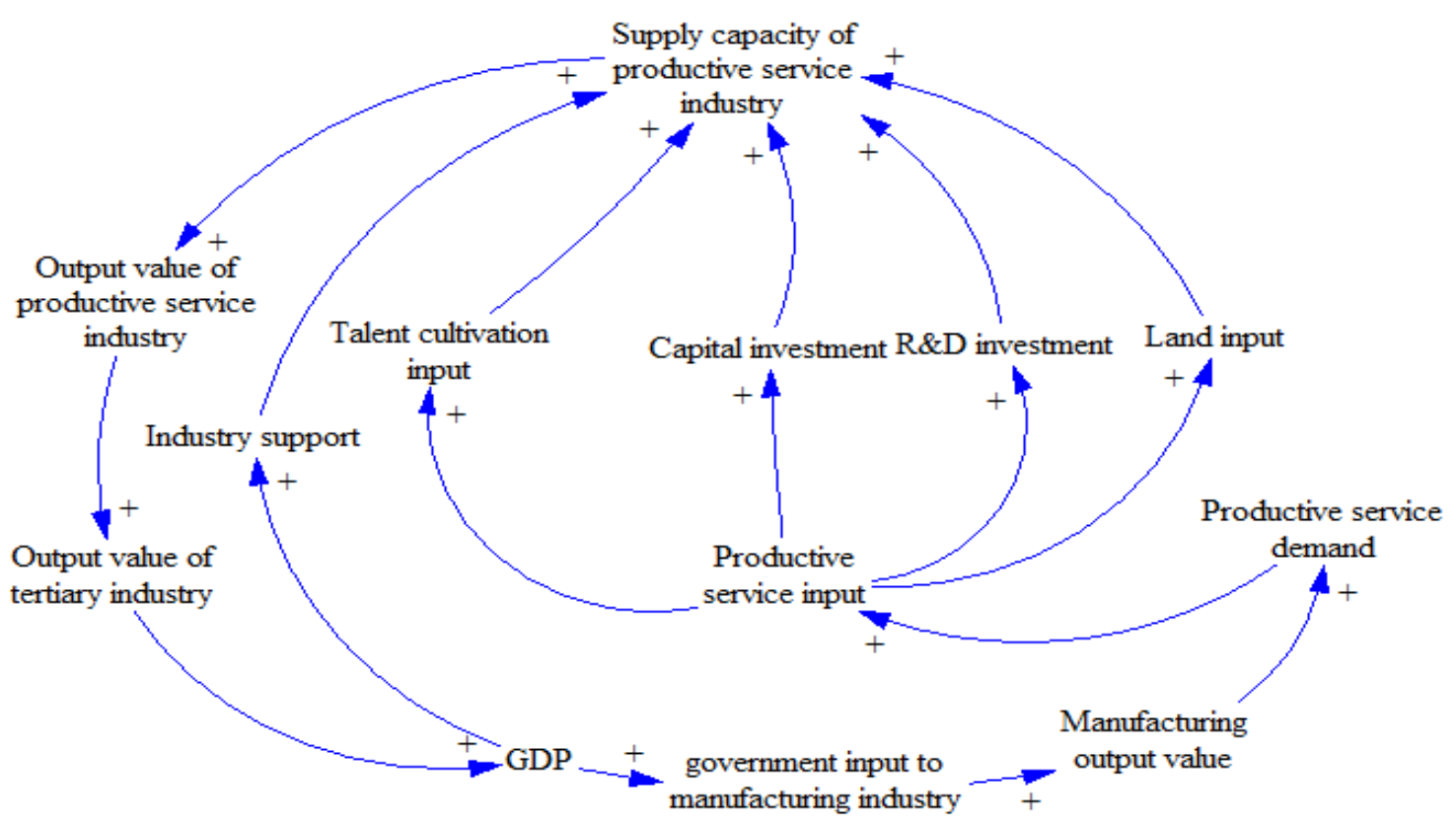

Figure 1. Productive service industry supply side reform causality model

Analysis of the main feedback loop of the system causality model. It can be seen from the model that the supply capacity of the productive service industry is affected by factors such as talent cultivation investment, capital, technology, land and industrial environment. The analysis of causal feedback loop is based on these factors. Provide an important basis for the formulation of the development strategy for the supply structure reform of the productive service industry[7].

Circuit 1: Supply capacity of productive service industry $\rightarrow$ Output value of productive service industry $\rightarrow$ Output value of tertiary industry $\rightarrow$ GDP $\rightarrow$ government input to manufacturing industry $\rightarrow$ Manufacturing output value $\rightarrow$ Productive service demand $\rightarrow$ Productive service input $\rightarrow$ Talent cultivation input $\rightarrow$ Productive Service industry supply capacity

Circuit 2: Supply capacity of productive service industry $\rightarrow$ Output value of productive service industry $\rightarrow$ Output value of tertiary industry $\rightarrow$ GDP $\rightarrow$ government input to manufacturing industry $\rightarrow$ Manufacturing output value $\rightarrow$ Production service demand $\rightarrow$ Productive service input $\rightarrow$ Capital investment $\rightarrow$ Productive service industry Supply capacity

Circuit 3: Supply capacity of productive service industry $\rightarrow$ Output value of productive service industry $\rightarrow$ Output value of tertiary industry $\rightarrow$ GDP $\rightarrow$ Government input to manufacturing industry $\rightarrow$ Manufacturing output value $\rightarrow$ Productive service demand $\rightarrow$ Productive service inpu $\rightarrow$ R\&D investment $\rightarrow$ Productive Service industry supply capacity

Circuit 4: Supply capacity of productive service industry $\rightarrow$ Output value of productive service industry $\rightarrow$ Output value of tertiary industry $\rightarrow$ GDP $\rightarrow$ Government input to manufacturing industry $\rightarrow$ Manufacturing output value $\rightarrow$ Productive service demand $\rightarrow$ Productive service inpu $\rightarrow$ Land input $\rightarrow$ Productive Service industry supply capacity

Circuit 5: Supply capacity of productive service industry $\rightarrow$ Output value of productive service industry $\rightarrow$ Output value of tertiary industry $\rightarrow$ GDP $\rightarrow$ Industry support $\rightarrow$ Productive Service industry supply capacity

The above five feedback loops are positive feedback loops, which mainly indicate that talent training investment, capital investment, technology investment, land investment, and industrial support will be beneficial to the improvement of the supply capacity of the productive service industry. 


\section{Development Countermeasures of China's Producer Service Industry under the Background of Supply Side Reform}

Increase the training of professional talents in productive service industry. In the process of accelerating the development of the productive service industry, increasing the training of professional talents is one of the issues we consider and solve. At present, there are problems in the number and capacity of productive service personnel in China. The government should increase investment in education, attach importance to vocational education, attach importance to the training of professional talents, establish a training system for vocational education personnel, establish a training base for talents, introduce various professional certifications, and cultivate more professional talents; establish an alliance of industry, academia and research, enterprises and schools together Cultivate applied talents and serve the productive service industry[8].

Improve the organic integration mechanism of productive service industry and manufacturing industry. With the rapid development of the global economy, the manufacturing industry is gradually showing a trend of service. Manufacturing enterprises are the main demanders of the productive service industry, and the manufacturing industry should promote mutual development with the productive service industry. It is necessary to continuously improve the interactive system of productive service industry and manufacturing industry; Increase government policy and financial support investment; The manufacturing industry needs to separate some non-core productive services and hand over the unskilled business to professional productive service companies, thereby improving the $R \& D$, design, logistics and service capabilities of the manufacturing industry[9].

Increase industrial policy support. In response to the policy of strictly controlling the productive service industry, China should increase policy support investment through means and appropriately relax policy control so that productive services and manufacturing policies enjoy the same policy treatment. Increase investment in guiding funds for China's productive service industry, and subsidize key service projects with strong influence, strong driving force and demonstration effect.

Improve the technical and management innovation ability of China's productive service industry. Management and technological innovation are of great significance to the development of China's productive service industry. At present, China's productive clothing innovation capacity is insufficient. On the one hand, the government should further improve the technology innovation policy system, increase investment in science and technology, and provide financial support for technological innovation; on the other hand, it should further strengthen management innovation in the fields of supply innovation, innovative thinking and innovation management[10].

\section{Acknowledgements}

Research Development Strategy of Dalian's Productive Service Industry on the Supply side Structural Reform under the New Normal Economy,2017 Dalian Social Science Project(2017dlskyb212)

\section{References}

[1] N. Sun: China Economic \& Trade Herald, (2017 ) No.8, p.14-16.

[2] X.Y. Wang,Q.Wang,D.Wu: Commercial Times, (2012) No.26, p.122-123.

[3] Q. Zhao: City, Vol. 11 (2016), p.70-76.

[4] L.Wang,S.C. Lu: Journal of Harbin University of Commerce (Social Science Edition), (2015) No.2, p.36-47.

[5] M.F.Liu,W.B. Yan: Science-Technology and Management, (2012) No.5, p.24-28.

[6] S.C.Zhang,X.H. Dong: Modern Management Science, (2013) No.7, p.94-96.

[7] Z.W.Wang,S.L. Deng: Science Technology and Industrial, (2012) No.3, p.32-35.

[8] J.Hu,S.H. Li: Journal of Anhui Business College, Vol. 14(2015) No.2, p.23-27.

[9] C.Y.Jing,C.F.Wang,Z.Q.Quan,M,Tang: Economic Research Guide, (2015) No.4, p.23-26. 
[10] M.Y.Li,Y.J.Deng,Z.Q.Quan,M,Tang: Journal of Guangdong Institute of Public Administration, (2015) No.5, p.74-81. 